\title{
A Survey on the Current Working Conditions and Job Satisfaction on Aquatic Therapy Performed by Physical Therapists
}

\begin{abstract}
Sejun Oh', Jin Yeong Jeon², Ji Hye Lee ${ }^{3}$, Byoung Yong Hwang ${ }^{4}$, BumChul Yoon ${ }^{5}$, Hyoung Chun Nam ${ }^{6}$ Jun Woo Yeom ${ }^{7}$
${ }^{1}$ Human Behavior \& Genetic Institute, Associate Research Center, Korea University; ${ }^{2}$ National Traffic Injury Rehabilitation Hospital; ${ }^{3}$ International Aquatic Therapy Association; ${ }^{4}$ Department of Physical Therapy, Graduate School, Young In University; ${ }^{5}$ Department of Physical Therapy, College of Health Sciences, Korea University; ${ }^{6}$ Department of Physical Therapy, Kyung Buk College; ${ }^{7}$ Department of Physical Therapy, Inje University Ilsan Paik Hospital, Seoul, Korea
\end{abstract}

Purpose: This study assessed the current working conditions and job satisfaction on aquatic therapy performed by physical therapists in South Korea.

Methods: A total of 139 (managers: 53, staff: 86) physical therapists participated in this survey (90 questionnaires) and the data were analyzed using the SPSS 21.0 Windows.

Results: The retention conditions of aquatic therapy facilitation was high in the rehabilitation centers (or disabled living facilities) and rehabilitation hospitals. On the other hand, there were regional variations. The physical therapists in this field were likely to have limitations or restrictions of professional aquatic therapy education. The subjects showed a tendency for a career interruption during their fifth working year. The overall job satisfaction on aquatic therapy of physical therapists was high (managers: $94.3 \%$, staff: 95.3\%, $p=0.276$ ), but the work intensity was higher than the other parts of physical therapy and the relative reward was comparatively low (managers: $60.3 \%$, staff: $66.3 \%, \mathrm{p}=0.865)$.

Conclusion: Based on this study, the current working conditions regarding aquatic therapy by physical therapists were assessed. These results will help enhance aquatic therapy and/or in aquatic therapy facilitation.

Keywords: Aquatic therapy, Current working conditions, Job satisfaction, Physical therapists, Survey

\section{서 론}

세계 물리치료 연맹(world confederation for physical therapy, WCPT)은 국제 수중 물리치료 협회(aquatic physical therapy international, APTI) 를 공식 네트워크(networks)로 인정하며, 국제수중치료협회(Switzerland)는 수중물리치료를 위한 교육연구 등의 국내·외 활발한 활동을 하고있다. 국제수중치료협회는 물리치료 선진 국가인 미국, 호주, 영 국 등을 비롯하여 총 34 개국 소속으로 구성되어 있고, 한국은 국제수 중치료협회 한국지부(international aquatic therapy association, IATAKOREA)로 포함되어 있다. 현재 국제수중치료협회 부회장인 요한 렘 벡(Johan Lambeck, physical therapist, Netherlands)은 근거 중심의 임상 및 연구에 목적을 두고 세계수중치료의 발전에 이바지 하고 있다.1,2
국제수중치료협회 한국지부에서는 국내 수중치료의 발전 및 전문 수중물리치료사 양성을 위해, 요한 렘벡을 중심으로 국내 수중치료 코스를 Level I (introductory course), Level II (Halliwick, Water Specific Therapy, Optional Course), Level III (special course: 1) Pediatrics, 2) Musculoskeletal, 3) Neurology), Level IV (lecturers course) 등으로 체계화하 여 양질의 국제 교육 및 세미나를 매 년 진행하고 있다. ${ }^{2,3}$

수중치료는 물의 특성을 이용하여 지상과 달리 신체의 생리적, 기 계적 효과를 보다 쉽게 얻을 수 있는 장점이 있어, ${ }^{4-6}$ 부력, 점성, 수온, 정수압 등을 이용하여 지상에서 어렵거나 불가능한 동작들을 가능 하게 할 수 있다는 장점이 있다. 또한, 환경 변화에 따른 회전 효과는 관절에 대한 역학 반응(arthrokinetic reaction)을 촉진시키고 자세안정 성을 향상시킬 수 있어 지상과 구별되는 뚜렷한 효과와 특성이 있다.
Received Jan 7, 2019 Revised Feb 4, 2019

Accepted Feb 25, 2019

Corresponding author Jun Woo Yeom

E-mail runner-j@hanmail.net
Copylight (C)2019 The Korean Society of Physical Therapy

This is an Open Access article distribute under the terms of the Creative Commons Attribution Non-commercial License (Http:// creativecommons.org/license/by-nc/4.o.) which permits unrestricted non-commercial use, distribution, and reproduction in any medium, provided the original work is properly cited. 
이에, 뇌졸중, 척추손상, 소아 등 신경계 손상 환자와 근골격계 손상 및 스포츠재활에 이르기까지 폭넓게 적용할 수 있는 물리치료 중재 방법 중 하나로 사용되고 있다.8-10

국내 수중치료는 종합병원에서부터 복지관에 이르기까지 다양한 기관에서 시행되고 있다. 그러나 각 지역 또는 기관별로 치료 시간, 치 료방법, 시설관리 등이 상이하고," 국내에 수중치료 교육이 보급된 이후로 수중치료의 시설 파악 및 전문교육과 인력 등에 대한 정보가 부족한 실정이며, 수중치료의 시행과 관리에 있어 기준이 명확히 마 련되어 있지 않아 혼선과 어려움이 큰 상황이다.

근래에는 의료기관 인증 및 심사평가 등에 있어 국내 기준이 미비 하여 우선적으로 외국의 기준을 적용하기 때문에 국내 환경에서 적 용하기에 현실과 맞지 않는 상황이 생겨나고 있다. 이에 수중치료 전 담 물리치료사가 근무 및 치료의 전문성에 대한 어려움으로 업무 기 피 현상이 나타나고 있으며, 심지어 비전문 인력에 의한 치료 및 운영 으로 효율성이 떨어지는 악순환이 반복되고 있다.

따라서 본 연구에서는 국내 물리치료사들이 수중치료의 이질적인 환경에서 오는 업무 수행의 어려움을 파악하기 위해 근무 실태 및 만 족도를 조사하여 국내 수중치료의 현황을 파악하고 인지하여 개선 사항을 도출하고자 한다.

\section{연구 방법}

\section{1. 연구대상자}

본 연구의 대상은 전국의 수중치료실을 보유하고 있는 기관 중 대학 병원, 종합병원, 재활·요양병원, 병·의원, 특수목적병원 (산재, 교통, 보훈, 재활원 등), 복지관 및 생활시설 (요한의 집 등), 기타 시설 (발달 센터·연구소)의 근무하는 물리치료사들을 대상으로 근무 실태 및 만족도 조사를 설문으로 진행하였다.
대상기관은 국제수중치료협회 한국지부, 건강보험심사평가원, 한 국사회복지관협회 등에 등록되어 있는 전국의 기관 중 수중치료실 보유 여부를 국제수중치료협회 소속 물리치료사 4 명이 유·무선으로 직접 파악하여 선정하였다.

본 연구를 위한 자료 수집은 2017년 3월-2018년 2월까지 설문지를 해당기관별로 수중치료실에서 근무하는 물리치료사들의 현황을 파 악하여 우편과 이메일, 직접 방문을 통하여 배부 및 회수하고, 부실 설문지를 제외한 총 설문 결과를 본 연구에 적용하였다.

\section{2. 연구도구 및 방법}

본 연구에서 사용 한 수중치료 근무 실태 및 만족도 조사 설문지는 $\mathrm{Cheon}^{12}$, Lee 등 ${ }^{13}, \mathrm{Kim}^{14}$ 의 설문지를 일부 인용하였고, 수중치료를 실 시하는 물리치료사들의 실태에 맞게 재구성하여 '국내 물리치료사 의 수중치료 근무 실태 및 만족도 조사' 설문지를 작성하였다. 설문지 의 구성을 위하여 물리치료사 2 명, 수중임상전문가 4 명, 물리치료학 과 교수 3 명이 사전 회의 10 회를 거쳐 재검토 및 심사를 하여 작성하 였다.

설문지 내용은 총 90 문항으로 근무 실태 관련 사항' 34 문항, '수질 및 시설관리 관련 사항' 18 문항, '직무만족 관련 사항' 38 문항으로 구 성되었다. 설문지 문항은 Table 1 과 같다. '수질 및 시설관리 관련 사항' 은 수중치료실을 책임지는 선임 치료사 1 인 (관리자)에게만 설문내용 을 추가하였고, '직무만족 관련 사항의 문항은 리커드 5점 척도를 이 용하였다. 전국 수중치료실 보유 현황은 건강보험심사평가원에서 제 공하는 종합병원, 전문병원, 요양병원, 병의원 1,803 개 기관과 한국장 애인복지관협회에 등록된 복지관 226개에 유선 연락하여 수중운동 치료 시설 여부를 파악하였다. 또한, 국제수중치료협회의 교육 참가 자료를 통하여 수중치료시설 보유현황을 보강하여 파악하였다.

Table 1. Survey on the working conditions and satisfaction survey of aquatic therapy of domestic physical therapist questionnaire

\begin{tabular}{|c|c|c|c|}
\hline Items & Number & Sub-Items & Number \\
\hline \multirow[t]{4}{*}{ Working status factor } & 34 & Physical therapist basic information & 6 \\
\hline & & Work institutions and regions & 2 \\
\hline & & Work condition & 15 \\
\hline & & Aquatic therapy implementation & 11 \\
\hline \multirow[t]{2}{*}{ Water quality and facilities management factor } & 18 & Water quality & 7 \\
\hline & & Facilities & 11 \\
\hline \multirow[t]{7}{*}{ Job satisfaction factor } & 38 & Job factor & 4 \\
\hline & & Equity with other physical therapy parts in the institution & 4 \\
\hline & & Job environment & 6 \\
\hline & & Relationship with senior & 6 \\
\hline & & Relationship with colleague & 6 \\
\hline & & Salary details & 7 \\
\hline & & Institution and change jobs & 5 \\
\hline
\end{tabular}




\section{3. 자료분석}

본 연구의 분석을 위한 자료는 SPSS 21.0 window를 이용하였다. 연구 문제와 관련하여 적용된 분석과 검정을 위해 사용될 구체적인 자료 분석방법은 다음과같다.

첫째, 수중치료를 시행하는 국내 물리치료사의 근무실태 사항 및 기초자료에 대한 빈도와 백분율을 산출하였다.

둘째, 전반적인 문항별, 요인 별 직무만족도를 관리자 및 실무자를 각 그룹별 비교하기 위해 시점별 독립 t-검정(independent t-test)을 실
시하였다. 유의수준은 0.05 로 설정하였다.

\section{결 과}

\section{1. 대상자의 일반적 특성}

본 설문의 총 응답수는 관리자(manager) 53 명, 실무자(staff) 86 명으로, 수중치료의 업무를 담당하고 있는 치료사 중 '성별' 은 관리자와 실무 자 모두 남성이 각 $67.9 \%, 55.8 \%$ 로 많았으며, '연령' 은 관리자는 40 세

Table 2. Participation general characteristics

\begin{tabular}{|c|c|c|c|c|c|c|c|}
\hline \multirow{2}{*}{ Item } & \multirow{2}{*}{$\begin{array}{c}\text { Manager } \\
\text { Frequency (\%) }\end{array}$} & \multirow{2}{*}{$\begin{array}{c}\text { Staff } \\
\text { Frequency }(\%)\end{array}$} & \multirow{2}{*}{$\mathrm{p}$} & \multirow{2}{*}{ Item } & \multirow{2}{*}{$\frac{\text { Manager }}{\text { Frequency }(\%)}$} & \multirow{2}{*}{$\begin{array}{c}\text { Staff } \\
\text { Frequency }(\%)\end{array}$} & \multirow{2}{*}{$p$} \\
\hline & & & & & & & \\
\hline Gender (man/woman) & $38(67.9) / 15(26.8)$ & $48(55.8) / 38(44.2)$ & 0.283 & Clinical career (year) & $11.06 \pm 6,52$ & $5.97 \pm 4.18$ & 0.000 \\
\hline Age & & & 0.536 & Aquatic therapy career (year) & $5.84 \pm 4.40$ & $4.16 \pm 8.02$ & 0.668 \\
\hline $23-26$ & $1(1.8)$ & $17(19.8)$ & & Education completion & & & 0.183 \\
\hline $27-30$ & $9(16.1)$ & $29(33.7)$ & & Halliwick introduce course & $35(66.0)$ & $16(13.0)$ & \\
\hline $31-34$ & $12(21.4)$ & $21(24.4)$ & & Halliwick main course & $34(64.2)$ & $3(2.4)$ & \\
\hline $35-39$ & $12(21.4)$ & $14(16.3)$ & & Bad Ragaz Ring Method introduce course & $13(24.5)$ & $0(0)$ & \\
\hline 40 & 19 (33.9) & $5(5.8)$ & & Bad Ragaz Ring Method main course & $13(24.5)$ & $0(0)$ & \\
\hline Nonresponse & $3(5.4)$ & $0(0)$ & & Watsu introduce course & $28(52.8)$ & $5(4.0)$ & \\
\hline Marriage & & & 0.123 & Watsu main course & $15(28.3)$ & $1(0.8)$ & \\
\hline Married person & $35(66.4)$ & $33(38.4)$ & & Ai-chi introduce course & $15(28.3)$ & $1(0.8)$ & \\
\hline Unmarried person & $18(33.6)$ & $53(61.6)$ & & AT\&RI introduce course & $11(20.8)$ & $2(1.6)$ & \\
\hline Academic career & & & 0.478 & AT\&RI main course & $9(17.0)$ & $1(0.8)$ & \\
\hline Associate degree & $12(22.6)$ & $23(26.7)$ & & Other course & $6(11.3)$ & $1(0.8)$ & \\
\hline Bachelor's degree & $23(43.4)$ & $51(59.3)$ & & Uncompleted course & $9(17.0)$ & $18(14.6)$ & \\
\hline Master's degree & $15(28.3)$ & $12(14.0)$ & & Education cost & & & 0.283 \\
\hline Doctor's degree & $3(5.7)$ & $0(0)$ & & Own expense & $15(28.6)$ & $39(36.8)$ & \\
\hline Institution & & & 0.088 & Institution expense & $12(23.5)$ & $32(30.2)$ & \\
\hline University hospital & $10(18.9)$ & $15(17.5)$ & & Part own expense & $21(40.3)$ & $27(25.5)$ & \\
\hline General Hospital & $3(5.7)$ & $3(3.5)$ & & not applicable & $4(7.6)$ & $8(7.5)$ & \\
\hline \multicolumn{8}{|l|}{ Rehabilitation residential } \\
\hline Hospital & $11(20.8)$ & $29(33.7)$ & & Dress type & & & 0.009 \\
\hline Clinic & $2(3.8)$ & $10(11.6)$ & & Suit & $32(62.7)$ & $53(65.4)$ & \\
\hline \multicolumn{8}{|l|}{ Development center } \\
\hline Research institute & $1(1.9)$ & $2(2.3)$ & & Rashguard & $11(21.7)$ & $8(9.8)$ & \\
\hline Specialized hospital & $4(7.5)$ & $10(11.6)$ & & Swimsuit & $6(11.7)$ & $18(22.2)$ & \\
\hline Industry clinic & $0(0)$ & $0(0)$ & & General dress & $2(3.9)$ & $2(2.7)$ & \\
\hline $\begin{array}{l}\text { Community welfare center } \\
\text { \& disabled living facility }\end{array}$ & $22(41.5)$ & $17(19.8)$ & & Dress cost & & & 0.000 \\
\hline Work location & & & & Own expense & $2(3.7)$ & $16(13)$ & \\
\hline Seoul & $6(11.3)$ & $7(8.1)$ & 0.782 & Institution expense & 49 (92.5) & $102(82.9)$ & \\
\hline Gyeonggi-do & $22(41.5)$ & $25(29.1)$ & & Part own expense & $2(3.8)$ & $5(4.1)$ & \\
\hline Gangwon-do & $1(1.9)$ & $2(2.3)$ & & Shower goods cost & & & 0.784 \\
\hline Chung-cheong-do & $3(5.7)$ & $16(18.6)$ & & Own expense & $12(22.6)$ & $8(6.5)$ & \\
\hline Jeolla-do & $4(7.5)$ & $1(0.9)$ & & Institution expense & $34(64.2)$ & $87(70.7)$ & \\
\hline Gyeongsan-do & $14(26.4)$ & $25(29.4)$ & & Part own expense & $7(13.2)$ & $28(22.8)$ & \\
\hline Jeju-do & $3(5.6)$ & 10 (11.6) & & & & & \\
\hline
\end{tabular}

*multiple responses to cumulative frequency 
이상이 33.9\%, 실무자는 27-30세가 33.7\%로 가장 많았다 (Table 2). 수 중치료 시설을 보유하고 있는 기관은 경기도에 가장 많았으며, 기관 별로는 복지관이 $41.5 \%$ 이나, 실무자는 재활요양병원이 $33.7 \%$ 로 많은 치료사가 종사하고 있었다. 설문 응답자 중 수중치료의 경력은 평균 4-5년으로 관리자는 할리윅 코스(소개 강좌 66\%, 본 강좌 64.2\%) 및 WATSU 소개강좌(52.8\%)를 실무자는 할리윅 소개강좌(13\%)를 가장 많이 이수하였으나, 실무자의 $14.6 \%$ 는 어떠한 교육도 받지 않은 것으 로 나타났으며, 교육비는 관리자가 본인 일부 부담(40.3\%)으로 실무 자는 본인 부담(36.8\%)으로 주로 이루어지고 있었다. 또한, 치료 복장 의 이용 중 슈트가 관리자(62.7\%), 실무자(65.4\%) 순으로 착용이 많았 으며, 샤워용품 구입 비용에 대한 기관의 부담은 관리자(64.2\%), 실무 자-(70.7\%)으로 나타났다.

\section{2. 대상자의 근무 실태}

대상자 근무 실태는 다음과 같이 시설, 치료 업무 및 불편사항으로 나누었다(Table 3).

1) 시설

감염관리는 규정은 있음(67.9\%), 없음(22.6\%), 모름(9.5\%) 이었으며, 수질 검사법은 기관 자체시행(65\%), 외부 전문 업체 의뢰(35\%)이며, 수질관리 주체는 엔지니어(30\%), 치료사(52\%), 외부 전문 업체 $(10 \%)$ 로 나타났다.

전량 배수 주기는 매일(13.5\%), 주 단위(19.2\%), 월 단위(36.5\%), 년 단 위(9.6\%), 간헐적 (19.2\%), 안 함(1.9\%)로 나타났다. 부분 배수 주기는 매 일(37.3\%), 주 단위(33.3\%), 월 단위(7.8\%), 년 단위(0\%), 간헐적(11.7\%), 안 함 $(9.8 \%)$ 로 나타났다.

치료풀 평균 규모는 가로 $(476.13 \pm 337.71 \mathrm{~mm})$, 세로 $(550.55 \pm 481.12$ $\mathrm{mm})$, 깊이 $(114.30 \pm 38.44 \mathrm{~mm})$ 로 나타났다. 치료실 온도 평균은 수온 $\left(33.23 \pm 2.35^{\circ} \mathrm{C}\right)$, 실내 온도 $\left(26.85 \pm 3.36^{\circ} \mathrm{C}\right)$, 수온 모름 $(20 \%)$, 실내 온도 모름(47.5\%) 으로 나타났다.

정수시스템 방식은 샌드 필터(66\%), 페이퍼 필터(4\%), 광선(26\%), 기타 (4\%)로 나타났으며, 정수 시스템의 부품 교체 주기는 6개월 이하(6.4\%), 1 년 이하(21.3\%), 안 함(8.5\%), 모른다(36.2\%), 기타(27.7\%)로 나타났다.

수중운동 장비 보유 유무는 보유하고 있다(42.3\%), 보유하고 있지 않다(57.7\%)로 나타났으며, 수중운동 장비 보유현황은 under water treadmill (55.5\%), under water bicycle (25\%), aqua climber (11.1\%), aqua strider (5.6\%), aqua rower(2.8\%)로 나타났다. 또한 입수 보조 장비 또는 시설은 경사로(23.2\%), 계단(31.9\%), 이동식 리프트(15.9\%), 고정식 리프 트(18.8\%), 레일식 리프트(1.5\%), 기타(8.7\%)로 나타났다.

\section{2) 치료 업무}

치료하는 환자 연령대는 10대 미만 관리자(34\%), 실무자(27\%), 10-20대
관리자(20\%), 실무자(18\%), 30-40대 관리자(11\%), 실무자(11\%), 50-60대 관리자 $(27 \%)$, 실무자 $(31 \%), 70$ 대 이상 관리자 $(8 \%)$, 실무자(13\%)로 나타 났다.

치료하는 환자 질환군은 뇌혈관질환으로 관리자 $(60.6 \%)$, 실무자 (66\%), 척수손상으로 관리자(9.1\%), 실무자-(9\%), 근골격계 질환으로 관 리자(10.1\%), 실무자 $(9 \%)$, 희귀난치성 질환으로 관리자(10.1\%), 실무자 $(8 \%)$, 기타 질환으로 관리자(10.1\%), 실무자 $(8 \%)$ 로 나타났다.

선호 전문치료 영역의 뇌혈관질환은 관리자(77.5\%), 실무자(67.4\%), 척수손상은 관리자(4\%), 실무자(7.7\%), 근골격 계질환은 관리자(2\%), 실무자(11.9\%)이며, 희귀난치성 질환은 관리자(12.5\%), 실무자(2.2\%), 기타 질환은 관리자(4\%), 실무자(10.8\%)이다. 수중치료 적용 수가는 건강보험수가가 관리자(50\%), 실무자(74.7\%), 시범수가(산재·자동차 보험)는 관리자(2.3\%), 실무자(3.6\%), 비급여는 관리자(27.3\%), 실무자 (14.5\%), 바우처는 관리자(4.5\%), 실무자(3.6\%)로 나타났다.

주요 사용 수중치료 기법을 갖고 있는 응답은 관리자(83.1\%), 실무 자-(76.8\%)이며, '없다’ 응답은 관리자(16.9\%), 실무자(23.2\%)로 나타났 다. 주요 사용 수중치료 기법 종류 중 Halliwick은 관리자(50.8\%), 실무 자(72.1\%), Bad ragaz ring method는 관리자(13.6\%), 실무자(25.6\%), Watsu는 관리자(20.3\%), 실무자(0\%), Ai-chi는 관리자(5.1\%), 실무자 (0\%), AT\&RI는 관리자(6.8\%), 실무자(0\%), 기타는 관리자(3.4\%), 실무 자(2.3\%)로 나타났다.

수중치료 환자 평가의 실시는 관리자(56.6\%), 실무자(59.3\%), 미실시 는 관리자(43.4\%), 실무자(40.7)로 나타났다. 응급대처 교육의 실시는 관리자(30.3\%), 실무자(37.9\%), 미실시는 관리자(66.7\%), 미실시(62.1\%)

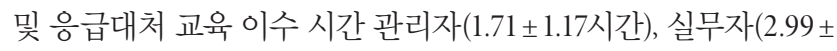
2.86 시간)로 나타났다. 전문치료사의 필요성은 '필요하다' 관리자 (81.1\%), 실무자(97.8\%), '필요하지 않다' 관리자(5.7\%), 실무자(1.1\%), '잘 모르겠다 관리자.(13.2\%), 실무자(1.1\%)로 나타났다.

\section{3) 불편사항}

수중치료 여성 치료사 시행은 '있다’ 관리자(52.8\%), 실무자(60.4\%), '없 다' 관리자(47.2\%), 실무자(39.6\%), 여성 치료사 월경 대처 방법은 '근무’ 관리자(30.4\%), 실무자(40.6\%), '대체인력 투입' 관리자(3.6\%), 실무자 (4.1\%), '휴무’ 관리자(8.9\%), 실무자(1.6\%), '기타' 관리자(5.4\%), 실무자 (1.6\%), '무응답' 관리자(51.4\%), 실무자(52.1\%)로 나타났다. 또한, 수중치 료 담당 시 불편사항은 '치료방법에 대한 이해 부족 관리자-(7.7\%), 실무 자(14.4\%), '신체· 생리적 문제' 관리자. $38.5 \%)$, 실무자(36.7\%), 시설· 환경 에 따른 문제' 관리자(48.7\%), 실무자(33.3\%), '안전사고 관리 문제 '관리 자(5.1\%), 실무자(15.6\%), '기타는 관리자(0\%), 실무자(0\%)로 나타났다. 


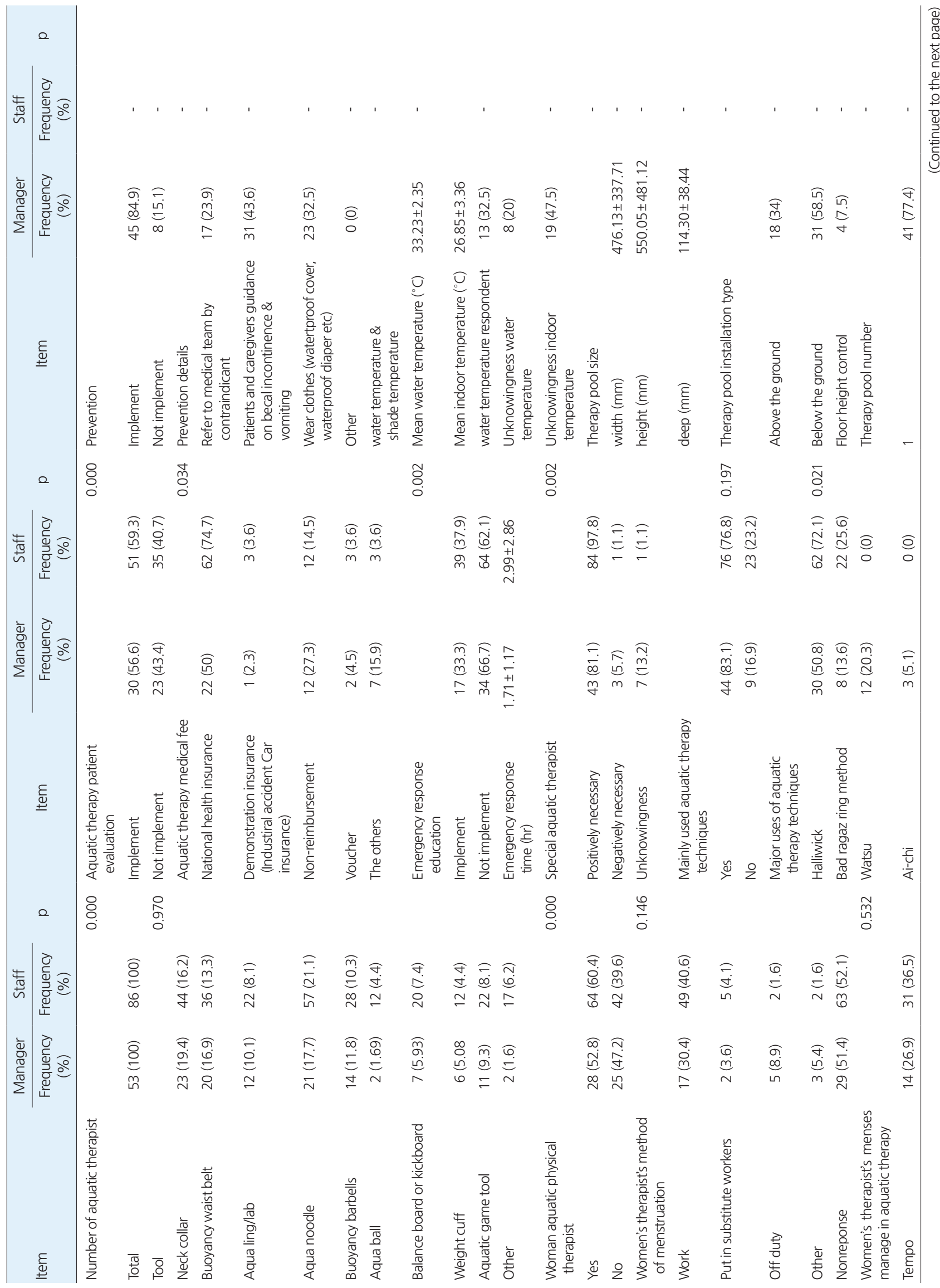




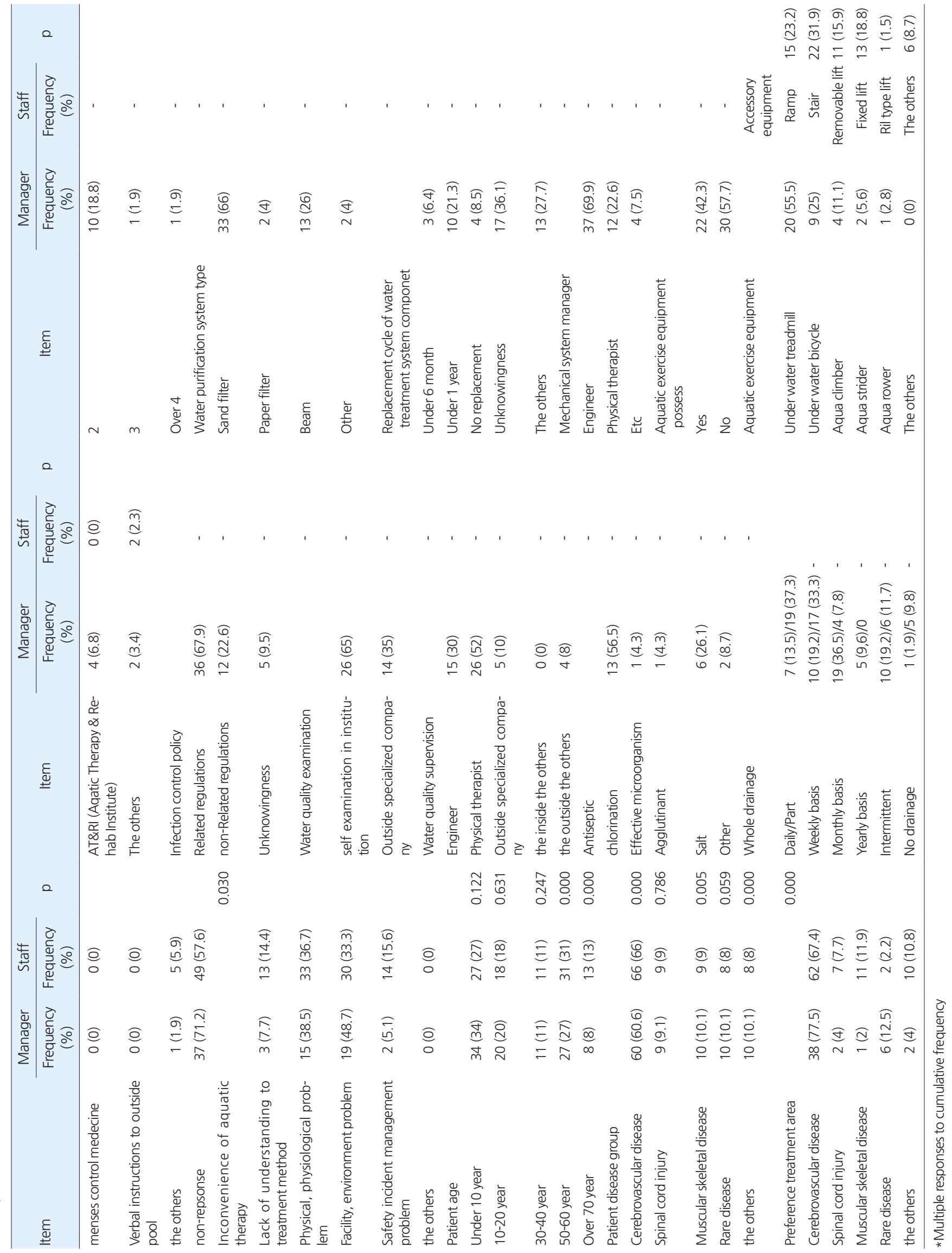


Table 4. Analysis of main issue to job satisfaction

\begin{tabular}{|c|c|c|c|c|c|c|c|c|c|c|c|}
\hline \multirow[b]{2}{*}{ Question } & Manager & Staff & \multirow[b]{2}{*}{$p$} & \multirow[b]{2}{*}{ Question } & Manager & Staff & \multirow[b]{2}{*}{$p$} & \multirow[b]{2}{*}{ Question } & Manager & Staff & \multirow[b]{2}{*}{$p$} \\
\hline & $\begin{array}{c}\text { Frequency } \\
(\%)\end{array}$ & $\begin{array}{c}\text { Frequency } \\
(\%)\end{array}$ & & & $\begin{array}{c}\text { Frequency } \\
(\%)\end{array}$ & $\begin{array}{c}\text { Frequency } \\
(\%)\end{array}$ & & & $\begin{array}{c}\text { Frequency } \\
(\%)\end{array}$ & $\begin{array}{c}\text { Frequency } \\
(\%)\end{array}$ & \\
\hline $\begin{array}{l}\text { I am satisfied with } \\
\text { the aquatic therapy } \\
\text { work }\end{array}$ & & & 0.276 & $\begin{array}{l}\text { Work intensity is } \\
\text { lower than } \\
\text { other parts }\end{array}$ & & & 0.865 & $\begin{array}{l}\text { My salary is appropriate } \\
\text { considering to career, } \\
\text { ability, and } \\
\text { professionalism }\end{array}$ & & & 0.084 \\
\hline Dissatisfaction & $2(5.7)$ & $2(4.7)$ & & Dissatisfaction & $32(60.3)$ & $58(66.3)$ & & Dissatisfaction & $23(35.8)$ & $39(43)$ & \\
\hline Satisfaction & $51(94.3)$ & $84(95.3)$ & & Satisfaction & 19 (35.9) & 28 (32.6) & & Satisfaction & $30(64.2)$ & $47(57)$ & \\
\hline $\begin{array}{l}\text { work with interest } \\
\text { and curiosity in } \\
\text { aquatic therapy } \\
\text { work }\end{array}$ & & & 0.622 & $\begin{array}{l}\text { Therapists have } \\
\text { enough to } \\
\text { relaxation area }\end{array}$ & & & 0.977 & $\begin{array}{l}\text { Treatment time and } \\
\text { frequency are lower } \\
\text { than other parts. }\end{array}$ & & & 0.139 \\
\hline Dissatisfaction & $2(3.8)$ & $2(1.2)$ & & Dissatisfaction & $28(49.1)$ & $20(25.6)$ & & Dissatisfaction & $18(32)$ & 35 (36.1) & \\
\hline Satisfaction & $51(96.2)$ & $84(98.8)$ & & Satisfaction & $25(50.9)$ & $66(74.4)$ & & Satisfaction & $35(68)$ & $51(63.9)$ & \\
\hline $\begin{array}{l}\text { I feel a sense of } \\
\text { accomplishment } \\
\text { and reward for the } \\
\text { aquatic therapy } \\
\text { work }\end{array}$ & & & 0.598 & $\begin{array}{l}\text { Supervisors } \\
\text { provide me with } \\
\text { helpful feedback }\end{array}$ & & & 0.008 & $\begin{array}{l}\text { I am living a leisurely } \\
\text { life now through } \\
\text { salary. }\end{array}$ & & & 0.002 \\
\hline Dissatisfaction & $2(3.8)$ & $2(2.4)$ & & Dissatisfaction & 10 (18.9) & 9 (10.4) & & Dissatisfaction & 18 (34.6) & 49 (56.4) & \\
\hline Satisfaction & $51(96.2)$ & 84 (97.6) & & Satisfaction & $43(81.1)$ & 77 (89.6) & & Satisfaction & $35(65.4)$ & 37 (43.6) & \\
\hline $\begin{array}{l}\text { I think that it is } \\
\text { socially recognized } \\
\text { in aquatic therapy } \\
\text { work }\end{array}$ & & & 0.048 & $\begin{array}{l}\text { A senior knows } \\
\text { and but also } \\
\text { respects } \\
\text { my work }\end{array}$ & & & 0.161 & $\begin{array}{l}\text { Currently, you have } \\
\text { not seriously } \\
\text { considered } \\
\text { change jobs }\end{array}$ & & & 0.008 \\
\hline Dissatisfaction & $5(9.4)$ & $24(27.9)$ & & Dissatisfaction & $7(13.2)$ & 10 (11.6) & & Dissatisfaction & 15 (28.3) & $35(40.7)$ & \\
\hline Satisfaction & 48 (90.6) & $62(72.1)$ & & Satisfaction & $46(86.8)$ & 76 (88.4) & & Satisfaction & 38 (71.7) & $51(59.3)$ & \\
\hline $\begin{array}{l}\text { Salary is not different } \\
\text { from other parts }\end{array}$ & & & 0.394 & $\begin{array}{l}\text { I am satisfied } \\
\text { with my pay }\end{array}$ & & & 0.048 & $\begin{array}{l}\text { The aquatic therapy is } \\
\text { respected by } \\
\text { colleague in other } \\
\text { parts (such as } \\
\text { land-based exercise } \\
\text { therapy) }\end{array}$ & & & 0.732 \\
\hline Dissatisfaction & $6(9.5)$ & $10(11.6)$ & & Dissatisfaction & $11(20.7)$ & $29(33.7)$ & & Dissatisfaction & $2(4.2)$ & $12(13.8)$ & \\
\hline Satisfaction & 47 (90.5) & 76 (88.4) & & Satisfaction & 42 (79.3) & $57(66.3)$ & & Satisfaction & $51(95.8)$ & $74(86.2)$ & \\
\hline
\end{tabular}

\section{3. 직무 만족도}

수중치료 업무의 '만족은 관리자(94.3\%) 실무자(95.3\%)로 나타났으며, ‘수중치료 업무의 흥미.호기심'의 ‘만족’은 관리자(96.2\%), 실무자 (98.8\%), '성취감. 보람'에 대하여 '만족은 관리자(96.2\%), 실무자(97.6\%), 사회적 인정은 관리자 (90.6\%), 실무자.(72.1\%)에서 '만족'으로 답하였 다(Table 4). 다른 파트와의 비교에 있어 '다른 파트와 급여의 차별성' 의 '만족은 관리자(9.5\%), 실무자(11.6\%)로 나타났다.

\section{고 찰}

본 연구는 전국 수중치료시설 보유기관을 파악하고, 물리치료사의 수중치료에 대한 전반적인 근무실태를 살펴보며, 직무만족도를 분석 을 하고자 하였다. 특히, 수중치료를 담당으로 하는 물리치료사중 기 관의 팀장급은 관리자로, 팀원들은 실무자로 설문을 나누어 분석하
여 세부적인 근무환경을 알아보고자 하였다. 이전 연구들은 국내 물 리치료사의 근무 현황에 대해 조사를 하였지만, 수중물리치료의 전 반적인 상황을 집중적으로 분석하지 않았고, ${ }^{15,16}$ 수도권 종합병원의 수중치료 현황에 대해 살펴본 연구는 약 10 년 전 수중 치료 현장을 분석을 하여," 현시대를 반영하는 최근 수중물리치료 연구가 필요하 다 판단하여 본 연구를 진행하였다.

주요 사항을 살펴보면, 첫째, 기관별 수중치료실 보유 현황은 기관 별로 '복지관 및 생활시설, 재활요양병원'이 제일 많은 것으로 조사되 었다. 환자들에 의한 수중치료에 대한 수요는 있지만, 종합병원 등은 시설 운영 등 타산이 맞지 않는 반면에, 운영이나 수익보다는 복지혜 택에 중점을 두고 있는 복지관에는 수중치료실을 보유하여 운영하 고 있는 것으로 나타났다. 수중치료는 신경계 환자의 급성기 후에도 긍정적인 효과가 있는 것으로 보고되고 있는데, ${ }^{17}$ 본 결과를 살펴보았 을 때, 종합병원에서의 수중치료실 운영 감소는 종합병원에 내원하 
는 근골격계 및 신경계 아급성기(subacute) 이후의 환자가 수중치료 의 안전하고 효과적인 중재를 통한 기능적 회복의 기회의 제한이 있 을 수 있다는 것을 시사한다.

둘째, 지역별 수중치료실 분포도는 지역별 수중치료실 총 분포도 는 경기도, 경상도, 충청도, 서울, 제주도, 전라도 및 강원도 순이었다. 경기도가 수중치료실이 가장 많은 이유 중 하나는 수도권 위성도시 들의 인구 증가(특히, 소아)와 더불어 나타나는 질병과의 관계성을 생 각해 볼 수 있었다. ${ }^{18}$ 반면, 전라도 및 강원도는 인구감소(특히, 소아) 와 더불어 수중치료실과 같은 의료시스템의 체계가 수도권에 비해 열악한 것으로 나타났다.

셋째, 이수 교육 차이는 관리자와 실무자의 수중치료 관련 전문교 육의 변수가 있었다. 일반적으로 수중치료 물리치료사는 5년 내외로 임상을 포기하는 경우로 지속적으로 교육을 받지 않거나, 기본강의 를 받고 끝나버리는 경우가 많다. 또한, 수중치료의 로테이션의 주기 가 급격히 빠른 것으로 사료되며, 수중치료의 실무자 역시 지속적인 근무가 이루어지지 않았다.

넷째, 복장은 슈트 착용에 대한 응답이 많았지만, 오히려 치료를 목 적으로 하는 수중치료실에서는 수영장과는 다르게 체온 보존에 큰 무리가 없는 환경이고, 슈트의 과도한 부력은 치료를 시행하는데 다 소 방해적 요소로 작용할 수 있어서 슈트에 대한 착용은 현실과 다르 게 부적합할 수 있으므로 치료사의 입장에서는 이 부분을 고려해야 한다.

다섯째, 교육비는 전문치료사를 통한 수중치료실의 효율적 운영이 필요하다는 의견이 관리자, 실무자.(76.8\%, 68.3\%) 모두 '필요하다는 의 견이 지배적으로 나타났으며, 특히 관리자에서 더 많은 필요성을 나 타났다. 조사를 통해 얻은 의견들과 같이 수중치료실을 갖추고 있는 각 기관들이 전문치료사 양성을 위해 교육비를 투자하는 환경을 조 성해주어 환자들이 양질의 수중치료를 받을 수 있도록 해야겠다.

여섯째, 응급상황에 대한 교육은 익사 사고뿐 만 아니라, 수중치료 실 내에서 간질, 심장마비 등 발생과 같은 돌발 상황에 대한 대처 교 육도 필요하다. 이에 대한 각 기관 내 응급사항 매뉴얼 배치 및 실질적 인 교육이 이루어져 돌발 상황에 대처할 수 있어야 할 것이다.

일곱째, 여성 치료사는 수중치료를 전담하는 치료사 남녀 비율의 불균형 원인으로 여성 치료사의 신체· 생리적 문제 (예: 월경 등)가 가 장 큰 이유로 여성의 주관적인 건강 상태를 고려하여 ${ }^{19}$ 각 기관의 지 속적인 관심과 세심한 배려 그리고 업무 로테이션, 적절한 휴식 등 현 명한 대처가 필요하겠다.

여덟째, 수중치료 주 치료 질환군은 수중치료의 주 치료 질환군이 뇌혈관질환으로 집중되어 있는 것은 급여 기준에 따른 신경계 질환 의 편중 현상으로 보인다. 따라서 수중치료가 필요한 근골격계 및 스 포츠 질환 등 세분화된 급여기준의 변화가 필요하다.
아홉째, 수중 평가도구 시행은 수중치료 시 평가의 미시행은 다른 파트(운동치료)에서의 평가로 대체한다고 하나 수중치료가 지상 치 료와 구별되어 차별성 있는 치료적 효과를 이루기 위해서는 수중환 경에서 환자의 상태를 객관적으로 평가할 수 있는 평가도구의 개발 과 함께 수중환경에서의 평가에 대한 급여 인정이 필요해 보인다.

열 번째, 수중치료 업무에 대한 전체적 만족도는 높은 것으로 나타 났다. 하지만, 세부적으로 살펴보면, 수중치료의 업무에 대한 성취감 과 보람을 느끼지만, 업무 강도는 다른 파트보다 전반적으로 높다고 평가하고 있으며, 급여에 대한 상대적 이득이 없는 것으로 나타났다. 따라서, 실무자들의 수중물리치료사 회피 현상이 일어나는 것이 아 닌가 생각된다.

본 연구의 제한점은 현재 국내에서 수중물리치료의 전반적인 사 회적 분석이 이루어지고 있지 않아 국내 수중치료 분석의 시대별 비 교 분석이 부족하다는 점이다. 따라서 본 연구가 향후 국내 수중치료 의 현황의 기반이 되어 앞으로도 세부적인 분석을 지속적으로 실시 하여, 국내 수중치료의 발전에 도움이 될 수 있도록 기여했으면 하는 바람이다.

결론적으로 본 연구는 국내 수중치료의 현황을 근무 실태 및 만족 도 조사를 통해 알아보았다. 수중치료 시설의 지역 불균형 및 환자 병 변에 따른 접근성, 실무자에 대한 지속적인 교육과 관심, 여성 물리치 료사의 근무환경, 객관적 평가에 따른 급여기준 마련 등의 현황 등의 주요 문제 현황을 도출하였다. 국내 물리치료사의 수중치료 업무 만 족도는 전반적으로 높았으나, 다른 파트보다 상대적으로 강도가 높고 급여는 적어 수중치료 근무의 지속성에 대한 어려움이 있음을 시사 하였다. 본 연구를 통해 수중물리치료의 현 상황을 인식하고 문제점 을 개선하여 국내 수중치료가 더욱 발전하는 계기가 되기를 바란다.

\section{ACKNOWLEDGEMENTS}

본 연구는 2016-2018년 국제수중치료 협회 한국지부(IATA-KOREA) 가이드라인 사업의 지원을 받아 수행되었음. 함께 도움을 주신 이종 필, 임현주, 오석, 박진훈 선생님께 감사의 마음을 전합니다.

\section{REFERNCES}

1. UK. World Confederation for Physical Therapy. https://www.wcpt. org/.2018.

2. South Korea, International Aquatic Therapy Association. http://www. iatakorea.com/.2018.

3. J. Lambeck. The halliwick concept, Part II. J Aquat Phys Ther. 2001;9:712.

4. Cruz S. A bicentric controlled study on the effects of aquatic Ai Chi in Parkinson disease. Complement Ther Med. 2018;(36):147-53. 
5. Marinho-Buzelli AR, Bonnyman AM, Verrier MC. The effects of aquatic therapy on mobility of individuals with neurological diseases: a systematic review. Clin Rehabil. 2015;29(8):741-51.

6. B.E. Becker. Aquatic therapy: scientific foundations and clinical rehabilitation applications. PM R. 2009;(1):859-72.

7. Kim TY, Kim GY, Lambeck J. Hydrotherapy in Rheumatoid Arthritis. J Kor Phys Ther. 2000;12(3):407-14.

8. Kim BW, Lee HJ. Effects of aquatic exercise therapy on motor function and balance in children with spastic cerebral palsy. Journal of Special Education \& Rehabilitation Science. 2015;54(1):75-94.

9. Kim DJ, Kim YM, Lee HM et al. The study on aquatic program development for shoulder injury patient. International Journal of Coaching Science. 2003;5(2):27-35.

10. Oh SE, Lee MY, Yeom JW et al. Effect of aquomanual therapy on pain and physical function of patients with chronic musculoskeletal disorders: a pilot study using quantitative and qualitative methods. Eur J Intergr Med. 2018;17:9-15.

11. Kim BG. Current status of pool therapy at general hospitals around the national capital region. Inje University. Dissertation of Master's Degree. 2002.

12. Cheon JK. A Study on the service performance and job satisfaction of physical therapists. J Kor Phys. 1991;3(1):9-37.

13. Lee HS, Song HK, Kim HN. The study work conditions and job satisfaction of physical therapist in Jeonnam east area. J Kor Phys Ther. 2005; 17(1):71-86.

14. Kim HA. A study on work conditions and the satisfaction of speech language pathologists. Wonkwang University. Dissertation of Master's Degree. 2012.

15. Bae SS, Park RJ. Present conditions and course of korea physical therapy. J Kor Phys. 1998;10(1):223-227.

16. Rha KY, Oh YT, Moon HM et al. A survey on working present status of physical therapiests in korea. J Kor Phys. 1998;10(1):229-239.

17. Tripp F, Krakow. Effects of an aquatic therapy approach (Halliwick-therapy) approach (Halliwick-therapy) on functional mobility in subacute stroke patients: a randomized controlled trial. Clin Rehabil. 2014;28(5): 432-9.

18. Kim US, Kim JH. Changes in the demographic structure and policy implications of Gyeonggido. Gyeonggi Research Institute. 2014;04:1-25

19. Lee SY, Lee JH. An analysis of factors influencing self-rated health in menstruating women: using Korean national health and nutrition. Examination survey (KNHANES). Korean Association For Learner-Centered Curriculum And Instruction. 2018;18(11):665-80. 